\title{
Review Essays
}

\section{A New Volume of Perfect Words}

\section{David Litwa's Hermetica II}

\author{
Dylan M. Burns \\ University of Amsterdam, Amsterdam, The Netherlands \\ d.m.burns@uva.nl
}

M. David Litwa, Hermetica II: The Excerpts of Stobaeus, Papyrus Fragments, and Ancient Testimonies in an English Translation with Notes and Introductions (Cambridge: Cambridge University Press, 2018). IS B N: 978-1-107-18253-O

The main impetus for this book is the absence of an up-to-date English translation of significant materials, mostly pertaining to 'philosophical Hermetica'-philosophically-inclined literature of Roman and late antiquity that features the Hellenistic Egyptian culture-hero Hermes Trismegistus ("thricegreatest") — that are not found in Brian Copenhaver's celebrated 1992 Cambridge translation of the Corpus Hermeticum and Latin Asclepius. ${ }^{1}$ The mate-

1 Brian Copenhaver, tr., Hermetica: The Greek 'Corpus Hermeticum' and the Latin 'Asclepius' in a new English translation, with notes and introduction (Cambridge: Cambridge University Press, 1992).

Abbreviations of Hermetic fragments and testimonies:

FH: $\quad$ Fragments of Hermetica

SH: $\quad$ Stobaeus (Fragments of) Hermetica

тH: $\quad$ Testimonies of Hermetica

Abbreviations of modern resources on Hermetica:

CHD: Jens Holzhausen, tr., Corpus Hermeticum Deutsch (2 vols.; Stuttgart-Bad Cannsatt: Frommann-Holzboog, 1997).

Litwa: $\quad$ M. David Litwa, Hermetica II, under review here. 
rials here presented by Litwa include: the many fragments quoted by the late antique anthologist John Stobaeus (early fifth century CE?); relatively recentlypublished papyri of Hermetic texts found at Vienna and Oxford; fragments of Hermetic works quoted by late ancient and medieval authors; and ancient and medieval testimonies about Hermes and the books associated with him (see further Litwa's own remarks in the volume under review, 1-2).

As far as the texts themselves go, this volume offers a great deal of material for which up-to-date English translations have been entirely lacking, as well as material not always found in comparable French and German resources. Litwa's Hermetica II gives the first scholarly, English-language translation of the Stobaeus fragments since that of Walter Scott, published in $1924 .{ }^{2}$ The Vienna fragments first published in 1951, whose text was improved and translated by Jean-Pierre Mahé in $1984,{ }^{3}$ as well as the Oxford fragments first published by Joseph Paramelle and Jean-Pierre Mahé in $1991,{ }^{4}$ appear here in English for the first time. The Stobaeus, Oxford, and Vienna fragments are followed by fragments of Hermetic texts quoted by authors from Tertullian to Nicholas of Cusa. The first 37 of these also appear in the still-classic edition and translation of Arthur Darby Nock and André-Jean Festugière (NF) and follow the numbering given there. A few fragments omitted by NF despite their inclusion of other fragments by the same author (such as Tertullian or Zosimus) are also given here by Litwa (175), as are other fragments which do not appear in Jens Holzhausen's 1997 Corpus Hermeticum Deutsch (CHD). ${ }^{5}$

NF: Arthur Darby Nock und André-Jean Festugière, eds. and trs., Corpus Hermeticum (4 vols.; Paris: Les Belles Lettres, 1946-1954).

2 Walter Scott, tr. Hermetica: The Ancient Greek and Latin Writings which contain Religious or Philosophic Teachings ascribed to Hermes Trismegistus. Volume 1: Texts and Translation (Oxford: Clarendon Press, 1924).

3 Jean-Pierre Mahé, 'Fragments hermétiques dans les papyri Vindobonenses graecae $29455^{\circ}{ }^{\circ}$ et 28928r', in Mémorial André-Jean Festugière: Antiquité païenne et chrétienne, edited by Enzo Lucchesi and Henri-Dominique Saffrey (Geneva: Cramer, 1984), 51-64, as well as Litwa's discussion (171).

4 Joseph Paramelle and Jean-Pierre Mahé, 'Extraits hermétiques inédits dans un manuscrit d'Oxford,' Revue des Études Grecques 104 (1991): 109-139.

5 For example, Malalas (Litwa, 216) is mentioned in NF 4:148, while the fragments quoted in the Tübingen Theosophy are given short shrift by Nock (NF 4:147-148) on grounds of their spuriousness but a more full discussion in Litwa (217-219). Fragments translated by Litwa and not to be found in NF or $C H D$ are from Gregory of Nazianzus, Gaius Iulius Romanus, Quodvultdeus, Michael Psellus, Albert the Great, and Nicholas of Cusa. While Litwa for the most part includes more material in his sections of "fragments" and "testimonia" than do either $\mathrm{NF}$ or $C H D$, there are a few fragments that do not appear in Litwa but are to be found in the latter works (Bar Hebraeus, NF frg. 22a) or $C H D$ alone (Ps.-Justin, Exhortation to the Greeks; Ps.-Didymus the Blind, On the Trinity, mentioned in Litwa, 232, but without reference to the full discussion in $C H D, 589$ ). 
Finally, Litwa includes many testimonies about Hermes Trismegistus and Hermetic literature that are not found at all in $\mathrm{NF}^{6}$ and while some of Litwa's fragments and testimonia are discussed in $C H D$, they are at times only summarized. A major plus is the inclusion of Arabic testimonia-mainly (but not always) adapted from Kevin van Bladel's watershed 2009 monograph The Arabic Hermes ${ }^{7}$ - as well as Byzantine and medieval Latin sources such as Michael Psellus, the Book of Beibenian Stars, Albert the Great, and Nicholas of Cusa, all absent from NF and $C H D$. Some of these testimonia are valuable indeed: for instance, a scholarly English translation with up-to-date bibliography of the Emerald Tablet has been a desideratum for some time, and Litwa furnishes just

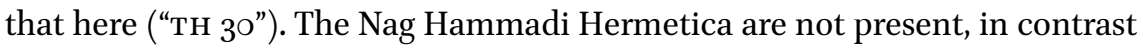
to $C H D$ and Mahé's recent supplement to NF published by Les Belles Lettres. ${ }^{8}$ Litwa, 1 is right that these translations are readily available, yet the omission does subtract somewhat from the overall value of the two Cambridge Hermetica volumes as a set, since one of the most important extant Hermetic works - the Discourse on the Eighth and Ninth (NHC VI,6) - is not found in either volume.

The translations in Hermetica II are of a uniformly high quality, if occasionally idiosyncratic, and they usually engage those offered by other modern translators responsibly and to good effect (cf. the treatment of $\mathrm{CHD}$ at Litwa, 35, on SH $2 \mathrm{~B}$; $7 \mathrm{O} \mathrm{n.} 7$, on SH 11). Reference to other translations is neither systematic nor exhaustive; e.g., Litwa's fine emendation (234) in $\mathrm{FH} 39 \mathrm{~b}$

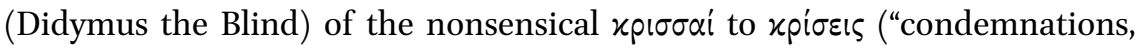
judgments") was suggested in $C H D 588 \mathrm{n} .42$, but not noted by Litwa. The fact that Litwa for the most part makes use of Nock's text as established in $\mathrm{NF}$ gives his translation a huge advantage over that of Scott, whose valiant, if at times deeply intrusive, treatment of the Greek texts remain worth consulting, but no longer serve as the primary point of departure for reading the Hermetic fragments and testimonia. In short, then, Litwa's translations in this volume are an enormous improvement upon those available in English up until now. They will be indispensable for English-language readers of Hermetic liter-

6 An exception is TH 20 (Hermias), which is discussed in NF 4:148-149 (not noted by Litwa).

7 See e.g. TH 25 (Al-Kindi), 26 (Abū Ma'shar), and TH 28 (ibn Fātik), per Kevin van Bladel, The Arabic Hermes: From Pagan Sage to Prophet of Science (Oxford: Oxford University Press, 2009), but cf. TH 27 (an-Nadìm), 3 o (Emerald Tablet), and even the Picatrix.

$8 C H D$ includes a translation of NHC VI,6 by Hans-Martin Schenke. See now also Jean-Pierre Mahé, ed. and tr., Hermès Trismégiste. Paralipomènes. Tome v: Codex vi de Nag HammadiCodex Clarkianus 11 Oxoniensis-Définitions hermétiques-Divers (Paris: Les Belles Lettres, 2019). 
ature, who have in recent decades been advised to turn to NF and $C H D$ for the Hermetic fragments and testimonia, even post-Copenhaver.

Meanwhile, a close look at Litwa's notes show that they are meant for newcomers to the Hermetic fragments, elucidating the texts by providing a sense of the many religious and philosophical texts and traditions to which the Hermetic literature alludes, and references to the secondary literature which the translator made use of in interpreting the primary sources. Overall, they are a bit light on Aristotle and the Stoa, while the Platonic tradition is wellrepresented (fitting, given Stobaeus's interests); Jewish and especially Egyptian sources are treated as well. The notes are not meant to replace a commentary or to solve questions of interpretation, which is no failure in itself-a real commentary would require a further volume altogether-but the Hermetic fragments and testimonies are famously obscure and difficult, and while less experienced readers may have to occasionally turn elsewhere for clarification, specialists will still need to keep Festugière's magisterial commentary in NF at hand. In the case of $\mathrm{SH}_{3}$, for instance, the obvious comparandum for the fragment is Greek De anima literature, but the requisite engagement with this literature on pages $40-41$ is limited to Plato. Other notes take something of a scattershot approach. SH 6.10, on the bodies of daimones and their status as the "energies" of the thirty-six decans, is annotated with apposite references to decans in Hermetic literature, ${ }^{9}$ but these are mixed in with general passages regarding Platonic demonology where decans in particular do not come into question. ${ }^{10}$ While the references are accurate, strictly-speaking, the untrained eye could take the latter sources as referring to decans as well as daimones, but they do not. References to key texts on Neoplatonic psychology from Plotinus to Iamblichus pop up in the notes to $\mathrm{SH}_{23}-25$, as they should, but the paucity of discussion belies an expectation of significant initiative on the part of a reader unfamiliar with these materials. The same could be said of the treatment of providence, fate, and necessity - primary themes of $\mathrm{SH} 7-8,11-16,18,20$, and 26 - or of matter.11 The commentary and notes of Festugière in NF are consulted only haphazardly; for example, Festugière's remarks are totally absent from Litwa's notes for SH 19 (cf. NF 3:cvi-cxiv, 84-85). Litwa rightly points to

Corpus Hermeticum 16.13 and Dorian Gieseler Greenbaum, The Daimon in Hellenistic Astrology: Origins and Influence (Ancient Magic and Divination 11; Leiden; Boston: Brill, 2016), 221.

Plato, Symposium 202d-203a; Plutarch, On the Obsolescence of Oracles 10-15; Maximus of Tyre, Discourses 8-9; Plotinus, Enneads, 3.4 [15] 3-6.

11 See the lonely reference to Plato, Timaeus 49a at 65, on SH 9, regarding the vexing problem of the status of matter in Greek philosophy. 
Iamblichus, De mysteriis 3.3 as a parallel for the notion of the two "lives of the soul," which SH 19 clarifies as referring to one "life" as noetic and selfdetermined ( $\left.\alpha \dot{\tau} \tau \varepsilon \xi \mathcal{V}^{\circ} \sigma 10 \varsigma\right)$ ), the other bound to the body and the constraint of cosmic Necessity ( $\alpha v \alpha \gamma \varkappa \alpha \sigma \tau i \kappa \eta \dot{)}$ ). Festugière (NF 3: 84 n. 7) offers further, apposite Iamblichaean parallels (from the commentary on Aristotle's De anima) absent in Litwa's notes.

Litwa's treatment of $\mathrm{SH}_{23}$, the famous, extended fragment of the Pupil of the World (Kore Kosmou), is representative of the volume's strengths and limits. The opening discussion and summary are exemplary and up-to-date, and offer proper context for work both in terms of Stobaeus's quotation of it as well as of late ancient religion and philosophy. The purple translation is in keeping with the flowery prose of the Greek, and overall, a laudable achievement indeed. Specialists can always quibble: for instance, the substantive $\tau \dot{0} \pi \varepsilon p \varepsilon^{\varepsilon} \chi 0 \mathrm{v}$, "that which surrounds" is a not uncommon substantive of the verb $\pi \varepsilon p i \varepsilon \chi(\omega$, and is taken in cosmological and physical contexts to refer to the upper atmosphere (LSJ 1373b). It appears in SH 23.7, 11, and 69. Litwa glosses the term somewhat misleadingly as $\delta$ $\pi \varepsilon p \varepsilon \dot{\chi} \chi \omega \nu$ (a form that does not appear in the text; we expect rather the neuter substantive), recognizes the sense, but renders it as "the ambient," with a note referring to the atmosphere $(108, n$. 22). Thus, we have the demiurgic Hermes who 'defended himself to the ambient since he had not entrusted the complete teaching to his son because of his young age.' "Ambient" is hardly idiomatic English; CHD's "Universum" is clearly closer to the sense, ${ }^{12}$ which in everyday English can be rendered simply with "heaven"; $; 3$ thus $\rightarrow$ "Hermes defended himself to heaven." Similarly sH 23.15, where the material that gives life, $\psi v \chi \omega \hat{\omega} \sigma \varsigma \varsigma$ (lit. 'ensouling, ensoulment'), is rendered 'animatrix' (Litwa, 110). Even setting aside the (intentional?) homonym with the 2003 Wachowski anthology of sci-fi shorts, "animation" is probably preferable to render $\psi v \chi \omega \hat{\omega} \sigma \varsigma \varsigma$ in English. ${ }^{14}$

Meanwhile, Litwa's introduction and notes to SH 23 are, in terms of general orientation, some of Litwa's strongest efforts in the volume, particularly as regards treatment of Egyptian sources. However, they do not give much in the way of analysis, as a look at a crux interpretationis makes clear: $\mathrm{SH} 23$ 's apparent

12 Cf. Scott, Hermetica, 463, 495: 'space around, ' atmosphere,' respectively; NF 4:2, 4: 'l' espace environnant'; ibid., 4:22, 'l' univers.'

13 See e.g. E.A. Sophocles, Greek Lexicon of the Roman and Byzantine Periods (from B.C. 146 to A.D.1100) (Cambridge; London: Harvard University Press, Humphrey Milford; Oxford University Press, 1914), 875b, s.v. 2; further, NF 4:49-50.

14 The Animatrix (prod. the Wachowskis, 2003). $\psi \cup \chi \hat{\omega} \sigma \mathrm{s}$ is rendered "animation" by NF 4:5 (italics Festugière's); $C H D, 425$ dodges by simply transliterating the word, "Psychosis" (despite glossing the word ad loc., "Beseelung"). 
depiction of Hermes not only as revealer but as a demiurgic figure, personally responsible for the forming of human bodies. Litwa mentions 'his (Hermes's$\mathrm{DMB}$ ) deeds regarding the creation of human beings' (102), a phrasing which could give the misleading impression that demiurgy is a typical activity for Hermes in the ancient and medieval Hermetic literature, when it is not. As so often in Hermetic texts, the context for this development is Plato's Timaeus, in this case the demiurge's delegation of the creation and ensoulment of human bodies to "young gods" (Timaeus $42 \mathrm{~d}-47 \mathrm{e}, 69 \mathrm{c}-8 \mathrm{ge}) \cdot{ }^{15} \mathrm{In} \mathrm{sH} 23$, God summons the planets for a convocation, where He muses about creating humanity, and the planets 'perceived his intent for each god to provide, as each was capable, something to those who would be born' (sH 23.27, tr. Litwa, 114). Preferring Roman to Greek names in the ensuing catalogue of (at times dubious) gifts bestowed by each planet to human beings, Litwa renders the name of the planet 'Epun's as 'Mercury.' Litwa explains his choice as highlighting the god's 'planetary nature' (114 n. 54), but the move obscures the text's explicit use of the name Hermes for both Hermes (Trismegistus), revelator and father of Isis, and Hermes the planet, creator and overseer of human souls, and supervisor of cosmic Nemesis ( $\mathrm{SH} 23.29-3 \mathrm{O}, 38-42,48-49) \cdot{ }^{16}$ Although it is the most natural reading of the text as it stands, such an identification is not uncontroversial: Litwa is right to observe that several Hermetic fragments preserved by Lactantius do explicitly distinguish between Hermes Trismegistus and the figure of Mercury (Litwa, 186 n. 18, on Divine Institutes 1.11.61 = FH 5a; Epitome of the Divine Institutes 14.3 $=\mathrm{FH} 5 \mathrm{~b}$ ), and no less an authority than Festugière himself deigned to identify Hermes the planet with Hermes the revealing creator of humanity. ${ }^{17}$

In terms of formal presentation, the volume is extremely clean, and this reviewer was at pains to find much that could be improved. The description in the notes (e.g., 47 n. 16) of manuscripts F and P together simply as "FP" may be confusing next to other abbreviations with uppercase "F" (cf. "NF" = Nock/Fes-

15 Litwa rightly refers to this passage at 115 n. 58 , but it is not only Hermes who "takes on the role of the star gods" in SH 23, but each of the planetary deities mentioned in 23.28-29.

16 For identifying Hermes (the revelator) with Hermes-Mercury (the planet) in SH 23, see also CHD, 403 n. 215, 412-414; Christian Bull, The Tradition of Hermes Trismegistus: The Egyptian Priestly Figure as a Teacher of Hellenized Wisdom (Religions in the Graeco-Roman World 186; Leiden; Boston: Brill, 2018), 104, 119. Another case of this identification presents itself in the Discourse on the Eighth and Ninth NHC VI 62.16-20, discussed in Bull, op. cit., 99 .

17 NF 3:cxlv: 'Le passage sur les promesses des dieux ne constitue pas une anomalie dans cet ensemble au mode personnel: car la planète Hermès, qui parle ici quand vient son tour 29.1, est différente du dieu Hermès auquel est dû le récit, ou du moins ce dieu ne marquet-il aucunement qu'il ait quelque rapport avec la planète du même nom.' On the planet Hermes/Mercury in SH 23, see also ibid., 3:cxcv. 
tugière), perhaps because it looks like an abbreviation but does not appear in the list of abbreviations. Typos and confusions are very rare and almost never substantial ${ }^{18}$ — bravo. It is worth clarifying Litwa's discussion in the volume's introduction of the cryptic, fragmentary dialogue preserved in Demotic manuscripts (and one Hieratic manuscript) initially published by Richard Jasnow and Karl-Theodor Zauzich under the title, Book of Thoth. ${ }^{19}$ Litwa avers that although the contents of the Book of Thoth are rather different than those of the philosophical Hermetica, 'the genre and format of the Book of Thoth strongly resembles these writings' (10). ${ }^{20}$ Enticing as this Demotic evidence may be, Prof. Joachim Quack has convincingly shown that the leader of the dialogue in the Demotic work in question is in fact probably not Thoth (seriously mitigating the justification for giving the work the title 'Book of Thoth'). ${ }^{21}$ Nor does the work contain anything resembling the engagement with Greek philosophy we find in so many Hermetic sources. Rather, even if one stretches, thematic correspondences between the Demotic work in question and extant Greek Hermetic literature appear limited to cases like queries about animal intelligence, or the religious fixation on figures of animals. ${ }^{22}$ While the question of the rela-

18 Cf. however 'Secret book of james' at 33 n. $15 \rightarrow 1$ Apocalypse of James.

19 For the editio princips, see Richard Jasnow and Karl-Theodor Zauzich, eds. and trs., The Ancient Egyptian Book of Thoth: A Demotic Discourse on Knowledge and Pendant to the Classical Hermetica (2 vols; Wiesbaden: Harrassowitz Verlag, 2005), esp. 65-71 (on the text's relationship to the Greek Hermetica); for a heavily revised translation with new introduction published in a more accessible format, see idem, Conversations in the House of Life: A New Translation of the Ancient Egyptian Book of Thoth (Wiesbaden: Harrassowitz, 2014).

20 The context for the discussion is that 'partial support' for the thesis of Christian Bull (namely, the "philosophical Hermetica" are products of disenfranchised Egyptian priests) 'comes from the Book of Thoth.' See now Bull, Tradition of Hermes, esp. 197-198. For an early discussion of the relation between the work dubbed Book of Thoth by Jasnow and Zauzich and Hermetic literature (deciding on a "mediated relation"), see Jean-Pierre Mahé, 'Preliminary Remarks on the Demotic "Book of Thoth" and the Greek Hermetica,' Vigiliae Christianae 50:4 (1996): 353-363; for further bibliography, see Joachim Quack, 'Rezension von Richard Jasnow and Karl-Theodor Zauzich, Conversations in the House of Life. A New Translation of the Ancient Egyptian Book of Thoth', Enchoria: Zeitschrift für Demotistik und Koptologie 35 (2016/2017): 215-231, 215 n. 4.

21 Joachim Quack, 'Ein ägyptischer Dialog über die Schriebkunst und das arkane Wissen,' Archiv für Religionsgeschichte (2007): 259-294, 289, 290; idem, 'Rezension,' 226-229. Bull explains the discrepancy away with the argument that 'in the Greek Hermetica we find Hermes speaking about his homonymous divine predecessor' (Tradition of Hermes, 198 n. 41); but is it obvious that this is how the master in the Demotic text relates himself to Thoth?

22 For possibly shared interest in the question of animal intelligence, compare Jasnow and Zauzich, Conversations, §§ 291-292 (p. 87) and sH 4.1-5; see Jasnow and Zauzich, Ancient Egyptian Book of Thoth, 70; Mahé, "Preliminary Remarks," 357-358; Quack, “Ägyptischer 
tionship between this mostly Demotic evidence and the emergence of the Hermetic works participating in the Greek philosophical tradition certainly merits further investigation, it remains tentative indeed. Finally, one should also highlight an important set of allusions to 1 Enoch at SH 23.5-8, deeply neglected in the secondary literature but recently brought to prominence in a volume by John Reeves and Annette Yoshiko Reed that appeared roughly at the same time as that under review. ${ }^{23}$

With Hermetica II, Litwa has given what will remain for a very long time the definitive, English-language translation of Hermetic fragments and testimonia. The volume will surely contribute a great deal to the Anglophone study of the Stobaean fragments and Hermetica more widely. With Hermetica II, Litwa has rendered scholars of Hermetism, late ancient religion and philosophy, and esotericism a great service indeed. That Litwa's prodigious discussion hardly suffices in lieu of formal commentary reminds us of how rich these often neglected Hermetic fragments and testimonia are-and, perhaps, that a Hermetica III may be in order, to help us make sense of them all.

Dialog,' 289-29o. I share Kevin van Bladel's assessment of this parallel as 'probably fortuitous' ('Review of Richard Jasnow and Karl-Theodor Zauzich, eds. and trs., The Ancient Egyptian Book of Thoth, Bryn Mawr Classical Review 2006.05.19). The religious import of animal images is ubiquitous in the Demotic text, and the focus of an important scene in Discourse on the Eighth and Ninth NHC VI 62.1-10; Quack, "Ägyptischer Dialog,' 29o. Jasnow and Zauzich also recall the appearance of a stele of turquoise and (ostensibly) the House of Life in the Discourse (Ancient Egyptian Book of Thoth, 70, re: NHC vi 61.20, 61.30, 62.15; and $61.25-30,62.10-15$, respectively).

23 SH 23.5, tr. Litwa: 'He saw everything. When he saw, he understood, and when he understood, he had strength to disclose and to divulge it. What he understood, he inscribed ...'-likely an allusion to a passage from the Book of the Watchers (1Enoch 19.3) that also enjoyed a healthy reception in Alexandrian Christian sources of the later second and early third centuries (Clement of Alexandria, Extracts from the Prophets 2.1; Origen of Alexandria, On First Principles 4.4.8) and perhaps also the Astronomical Book (1Enoch 72-82). On SH 23.5's allusions to 1 Enoch and the passages' greater interface with early Christian sources, see Martin Hengel, Judaism and Hellenism: Studies in their Encounter in Palestine during the early Hellenistic Period (Philadelphia: Fortress Press, 1984) 1:213, and now John C. Reeves and Annette Yoshiko Reed, Enoch from Antiquity to the Middle Ages: Sources from Judaism, Christianity, and Islam. Volume One (Oxford: Oxford University Press, 2018), 82$83,272-274$. 